\title{
Optimizing selection of sexually mature Barbus altianalis for induced spawning: determination of size at sexual maturity of populations from Lake Edward and Upper Victoria Nile in Uganda
}

\author{
Cassius Aruho ${ }^{* *}$, Richard Ddungu ${ }^{2}$, Winnie Nkalubo ${ }^{3}$, Constantine Chobet Ondhoro ${ }^{4}$, Fredrick Bugenyi ${ }^{5}$ \\ and Justus Rutaisire ${ }^{6}$
}

\begin{abstract}
Sexual maturity $\left(L_{50}\right)$, the length at which $50 \%$ of fish in a size class are mature, is a key aspect of domestication of new fish species because it guides the procedure for identification of appropriate broodstock size for artificial spawning. In this study, the $L_{50}$ was determined for 1083 Barbus altianalis samples obtained from Lake Edward and the Upper Victoria Nile. Gonads of freshly killed samples were examined macroscopically and verified with standard histological procedures for the maturation stages that were used to determine $L_{50}$. Oocytes and spermatogenic cell sizes were compared for fish obtained from both water bodies. Results indicated that there were no variations in macro gonad features observed for fish from Lake Edward and Upper Victoria Nile. Similarly, there were no significant differences in oocyte sizes $(P>0.05)$ between the two populations but significant differences in spermatogenic cell sizes were noted $(P<0.05)$ except for spermatozoa $(P>0.05)$. This however did not suggest peculiar differences between the two populations for staging the gonads. Consequently, no staging variations were suggested for both populations in determination of $\mathrm{L}_{50}$. Sexual maturity was found in the same class size of fork length (FL) $20-24.9 \mathrm{~cm}$ and $35-39.9 \mathrm{~cm}$ for males and females from both water bodies, respectively. At this FL, however, males were too small, and for good selection of vigor broodstocks for spawning and conservation purposes, they are better picked from class size of 30-34.9 cm FL and above. These findings were crucial for integration of appropriate breeding size in spawning protocol by farmers and fisheries scientists conserving wild B. altianalis populations.
\end{abstract}

Keywords: Sexual maturation, Staging, Oocyte sizes, Spermatozoa

\section{Background}

Barbus altianalis also known as the Ripon Barbel is a freshwater cyprinid inhabiting the lacustrine-riverine system of Lakes Edward and Upper Victoria Nile in East Africa (Greenwood 1966). It is a high-value species and a cherished delicacy in the East African region. Its successful induced spawning by Rutaisire et al. (2015) was in response to the drastically declining catches in the region (Ondhoro et al. 2016; Rutaisire et al. 2015). The

\footnotetext{
*Correspondence: caruho@yahoo.com; aruhoc@gmail.com

${ }^{1}$ Aquaculture Research and Development Center, Kajjansi, PO Box 530,

Kampala, Uganda

Full list of author information is available at the end of the article
}

successful spawning triggered more research activities in technologies aimed at improving its availability for commercial production. For instance, the optimal spawning conditions and its larval growth performance has been improved to ensure mass seed production for distribution (Aruho 2017). However, during the improvement process of spawning, the appropriate size for spawning was found to be an important aspect required for inclusion in spawning protocol. The size at maturity is the size at which $50 \%$ of the fish in a given class size is sexually mature (Booth 1997). Length and weight are the most commonly used mean indices for estimating the size at which $50 \%$ of the fish become mature in a given 
class size (Hossain et al. 2012; Lambert et al. 2003). The size at maturity in fish is determined based on gonadal maturation and developmental patterns in a given species (Brown-Peterson et al. 2011; Lambert et al. 2003). Fish grows through egg-larval, juvenile, and mature ontogenetic phases which are genetically and environmentally controlled (Gunnarsson et al. 2006; Nickolskii 1969). Transformation from immature to sexually mature phases in teleosts is a critical developing period when the fish enters the reproductive cycle (Brown-Peterson et al. 2011). Thus, the transition from juvenile to sexual maturity in both females and males occurs when appropriate environmental and biological cues trigger the initiation and transformation for the first time of pre-vitellogenic oocytes and spermatogonia into vitellogenic oocytes and spermatozoa respectively. The attainment of size at maturity in the same species may vary with changing environmental conditions over time and in the same or different geographical locations (Cao et al. 2009; Lambert et al. 2003). The size at maturity has been determined for many teleosts and is regarded as a remarkable factor of reproductive potential that has been widely used in fisheries to control and regulate fish exploitation for sustainable conservation. Its use has apparently been extended into studies for domestication of fish species, guiding culturalists to identify sexually mature and ripe individuals for induced spawning (Aruho et al. 2013; Rutaisire and Booth 2004). Identification of suitable candidates for induced spawning requires adequate knowledge of the size of the fish with high chances of oocytes that have reached ripening stage ready for ovulation (Basiita et al. 2011; Rutaisire et al. 2015).

Although induced spawning was successfully achieved for B. atlianalis (Rutaisire et al. 2015), the appropriate size at sexual maturity was never determined. Any fish ranging from 100 to $7000 \mathrm{~g}$ could be used for spawning as long as it had milt or eggs and this is still the trend. However, this raised questions of conservational size and often heightened a potential conflict between fisheries, law enforcers, and breeding scientists as this was seen as a bad habit of encouraging fishers to catch undersized fish. Apparently, it is difficult to state the appropriate size of wild fish for inclusion in the breeding protocol of $B$. altianalis. In spite of the successful larval weaning and juvenile growth experiments that have been conducted to improve survival and growth of $B$. altianalis (Aruho 2017), the selection of an appropriate size for breeding is still an important requirement and this is still based on the wild source. This is because there has not been a reported breakthrough of the completion of the breeding cycle of $B$. altianalis in captivity. Rutaisire et al. (2015) recommended a semi-natural method as one of the propagation methods in which the brood fish could be collected, induced, and left to spawn naturally in ponds. However, the collection of wild species for acclimatization, conditioning, and subsequent domestication requires known length at sexual maturity. Knowledge of size at sexual maturity is an important reproductive aspect that was crucial in defining and integrating the right size of brood fish in artificial spawning protocol of $B$. altianalis. Thus this study focused on determination of appropriate size (length and weight) at maturity of $B$. altianalis from two populations of Lake Edward and Upper Victoria Nile to guide in selection of right fish size for induction during artificial spawning.

\section{Methods}

\section{Collection of wild fish samples for determination of size at maturity}

B. altianalis samples were collected from Lake Edward (S00.08835, E029.76159; S00.13530, E029.86539) and Upper Victoria Nile $\left(33^{\circ} 05^{\prime} \mathrm{E}, 0^{\circ} 35^{\prime} \mathrm{N}\right.$; $33^{\circ} 05^{\prime} \mathrm{E}, 0^{\circ} 45^{\prime}$ N) between February and April 2015. Samples from Upper Victoria Nile were collected using both hooks and nets. The hooks were of size 9-7 (14-13 mm hook gape size, respectively) mounted on long lines in a fleet of 100 $500 \mathrm{~m}$ in length and baited with tilapia fingerlings. The fishing nets were used for catching fish in both Upper Victoria Nile and Lake Edward. A fleet of nets each of ply 36, $26 \mathrm{~m}$ in width and $90 \mathrm{~m}$ deep (for Lake Edward) and $25 \mathrm{~m}$ in width and $10 \mathrm{~m}$ deep (for Upper Victoria River), with mesh size ranging from 0.5 to 10 inc. were joined together. However, the nets in Lake Edward were not fixed but left to drift in the fishing ground (this is the commonest method used by fishermen for catching $B$. altianalis in Lake Edward). The nets were set for $12 \mathrm{~h}$ at night and for three consecutive days. However, our experimental nets could not catch enough specimens and were therefore supplemented by purchasing all the landed fish on the sampling day. In total, 220 fish were captured with experimental nets from Lake Edward but 303 were purchased, while 200 fish were caught with experimental nets in Upper Victoria Nile but 360 fish were purchase at the landing sites. The total weight $(\mathrm{g})$ was recorded to the nearest $0.1 \mathrm{~g}$ and standard length (SL), fork length (FL), and total length (TL) were measured using a calibrated fish measuring board to the nearest $0.1 \mathrm{~mm}$. Fish was dissected to obtain the gonads that were classified into maturity stages based on modifications from Brown-Peterson et al. (2011) classification (Table 1 and Table 4). To validate the stages, small portions of gonads for each fish were immediately preserved in Bouin's solution for further histological analysis. The preserved samples were taken to the College of Veterinary Medicine, Animal Resources and Bio-security (COVAB) histology laboratory at Makerere University and were processed based on standard histological procedures by Bancroft and 
Table 1 Classification of maturity stages for female B. altianalis Stage I (immature): Strand-like reddish gonads (dominated by oogonia and primary growth oocytes)

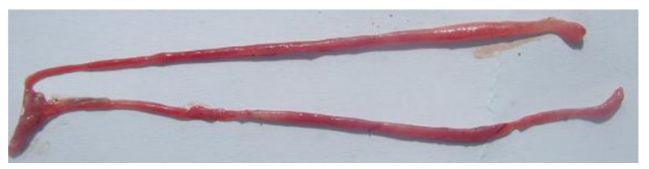

Stage III (spawning capable): Early stage; clear gonads with batches of off-white and pale yellow eggs. This stage is dominated by Vtg1 and Vtg2 oocytes. But still enlarging in size

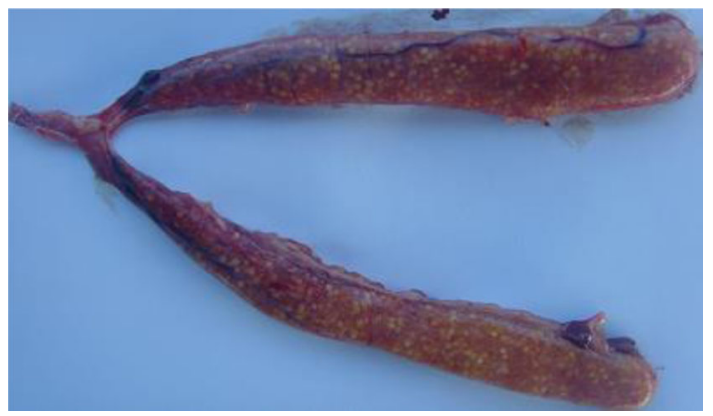

Stage IV (regressing): Flabby gonads with observed residual eggs Residues are degenerating atretic oocytes

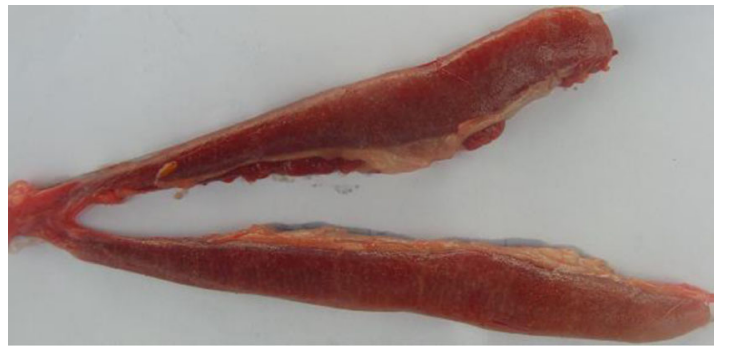

Gamble (2002). Tissue subsections of $5 \mu \mathrm{m}$ of the preserved gonads were dehydrated in different alcohol concentrations in an automatic tissue processor, embedded in wax, further sectioned with a microtome, mounted, rehydrated, and stained using Gill's hematoxylin and eosin (H\&E) and/or Masson's trichome (MT). The sections were then examined using a light microscope (model Leica DM 500, Made by Microsystems Switzerland Ltd) for identification of oocyte and spermatogenesis stages. The diameter of oocytes and spermatogenic cells were measured by sub sampling at least 5 oocytes for each type in each egg (in 17-25 ovaries from each lake) and at least 30 spermatogenic cells for each type in each testis (in 12-17 testes from each lake) under a light microscope with a calibrated stage micrometer in the eyepiece lenses. For the oocytes, three planes of oocytes and their nuclei diameters were measured and an average size was recorded. The number of nucleoli was counted for each nucleus and recorded.
Stage II (developing): Minute off-white speckles (cortical alveolar oocytes) are observed within the ovary. Few Vtg1 and Vtg2 are also observed

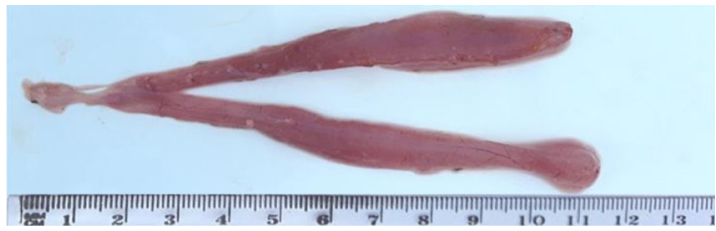

Stage III (spawning capable): Spawning stage; clear gonads with batches of off-white and pale yellow eggs parked in the ovary. The observed oocytes are largely dominated by Vtg3 and mature oocytes with some POFs. But all oocytes types are present qualifying it as a batch spawner

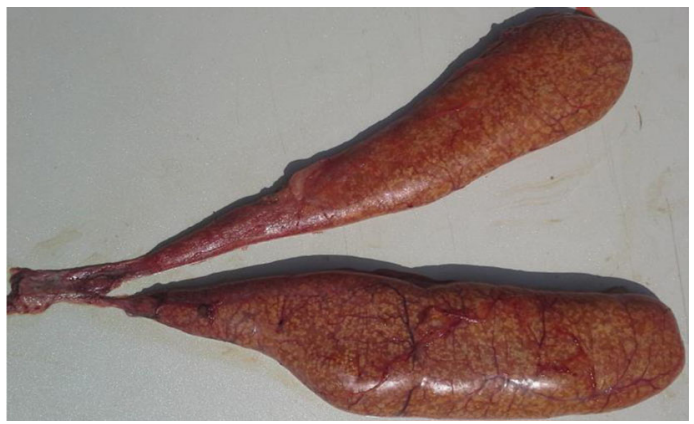

Stage V (regenerating): Same as II but slightly bigger. Old POFs, melano microphage centers, and $O O$ and PG oocytes are observed

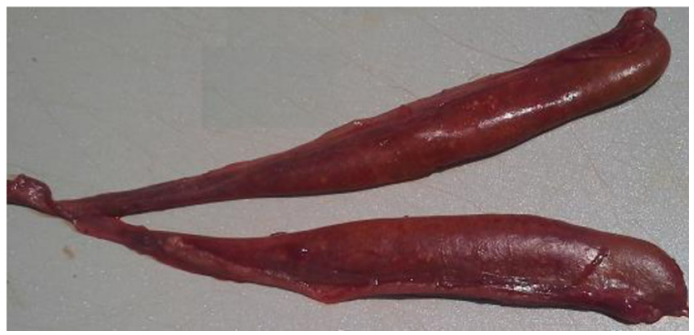

\section{Statistical analysis}

The differences in sex ratios of fish from each natural water body were estimated by use of a chi-squire method to determine if the ratios were significantly different from the hypothetical 1:1 female to male ratio. Differences in oocyte and spermatogenic cell sizes between fish from Lake Edward and Upper Victoria Nile were determined by student's $t$-test statistic. The fish were sampled as experimental units from Lake Edward and Upper River Nile using SPSS statistical software (IBM SPSS Statistics for Windows, Version 22.0. Armonk, NY: IBM Corp, 2013). The length at which $50 \%\left(\mathrm{~L}_{50}\right)$ of individuals in a class size were sexually mature was estimated from the ratio of the coefficients of a binary logistic regression of length and maturity level (mature; immature individuals). These coefficients $(\alpha$ and $\beta$ ) of the binary regression were estimated by Excel-solver statistical program in Excel micro software (Windows 2010). The length $\mathrm{L}_{50}=$ Alpha $(\alpha) /$ Beta $(\beta)$, where $\alpha$ and $\beta$ are the coefficients of a two-parameter non-linear model (Booth 1997) obtained by stabilizing the 
coefficients and fitting the logistic ogive curve using Excel-solver.

The two-parameter logistic ogive was described by the non-linear equation:

$$
P_{\mathrm{L}}=1 /\left\{1+\exp ^{(\alpha-\beta \mathrm{L})}\right\}
$$

where $P_{\mathrm{L}}$ is the predicted proportion of mature fish at length of the fish $L, \alpha$ and $\beta$ were coefficients of the parameter model. All individuals in developing phase (stage II) and above (stages II, IV, and V) were taken as mature individuals (Brown-Peterson et al. 2011). A regression between length and weight was run using Excel Microsoft to predict the corresponding weight at $\mathrm{L}_{50}$ for SL, FL, and TL (cm). Comparisons of coefficient $b$ of power equations obtained were based on Froese (2006). To obtain the size frequency distributions (number of sampled fish in each size class) for each size class for the collected data from each lake, individual sizes of fish were grouped in intervals of 5 units using a pivot table in Microsoft Excel. A graph of individual sizes was plotted against the class intervals.

\section{Results}

\section{Sex ratios}

A total of 523 specimens from Lake Edward were collected. Females were 314 while the males were 209, constituting a female to male ratio of 1:0.64 which was statistically different from the hypothetical $1: 1\left(\chi^{2}=18.00\right.$, $\mathrm{df}=1, P<0.001)$. Comparatively, there were 560 fish samples from Upper Victoria Nile. Females were 360 and males were 200 constituting a ratio of 1:0.56. This ratio was significantly deviating from the hypothetical 1:1 female to male ratio $\left(x^{2}=45.71, \mathrm{df}=1, P<0.001\right)$.

\section{Macroscopic and microscopic description of female classification stages}

Stage I was dominated by the oogonia and primary growth oocytes which included chromatin nucleolar oocytes and the perinuclear oocytes (Fig. 1a). Macroscopically, the female gonads in stage I were thread-like and transparent (Table 1). In stage II, the primary oocytes developed into cortical alveolar oocytes that later transformed into primary and secondary vitellogenic oocytes (Fig. 1b). Macroscopically, gonads in stage II begun to show minute speckles which later became large and began to fill up the gonad. The gonad became pale yellow as the primary and secondary yolk vesicles began to fill up the gonads (Table 1). In stage III, the secondary vitellogenic oocytes were transformed into tertiary vitellogenic oocytes and mature oocytes. Microscopically, all types of oocytes at this stage were present in the monthly samples indicating batch characteristic development (Fig. 1c). Macroscopically, the gonads swell in size and they became yellowish in color with off-white and yellow egg batches (Table 1, stage III). Stage IV had some post ovulatory follicles (POFs), atretic oocytes, and sometimes very few remaining oocytes (Fig. 1d). The gonad became regressed in size and had relatively bloody looking vessels (Table 1 , stage IV). In stage $\mathrm{V}$, only the oogonia and other primary growth oocytes were proliferating. This stage was distinguished from the virgin females by the presence of melano macrophage centers, some increased bloody vessels, old POFs, and atresia of most of vitellogenic stages. The gonad was further reduced but looked dark reddish and not transparent (Table 1, stage V).

There were no significant differences in oocyte sizes for each oocyte type between fish from Lake Edward and those from River Nile $(P>0.5)$ (Tables 2 and 3$)$.

\section{Macroscopic and microscopic description of male classification stages}

In stage I, only the primary spermatogonia were present. The testis was tiny, strand-like, and difficult to differentiate from that of the female. In stage II, spermatogonia developed into primary spermatocytes and secondary spermatocytes (Fig. 2a). In stage II, however, few of the secondary spermatocytes had transformed into spermatids and into spermatozoa. The gonads looked off-white with serrations or appearance of lobulations (Table 4). In late stages for stage II, a number of spermertocytes transforming into spermatids and spermatozoa increased. Stage III was characterized by the presence of all spermatogenic cells dominated by the spermatozoa (Fig. 2b). The gonads were bigger than other stages with off-white coloration (Table 4). In stage IV, the number of sperms reduced tremendously living large empty spaces, though there was still presence of all other spermatogenic cells. The gonads were bloody looking. Stage V was characterized by the presence of many spermatogonia with very few residual spermatozoa only.

Significant differences in sizes were observed in spermatogonia, spermatocytes, and spermatids between the individuals from Lake Edward and those from Upper Victoria Nile (Table 5). However, no significant differences were observed with spermatozoa between the two populations $(P>0.05)$. All the spermatogenic cells of males from the Upper Victoria Nile were slightly bigger than those from Lake Edward.

\section{Size at sexual maturity, $\mathrm{L}_{50}$ from Lake Edward and River Nile}

Females and males from Lake Edward reached their sexual maturity at an earlier stage (smaller size) than those from Upper Victoria Nile. Length at maturity $L_{50}$ for females from Lake Edward and the Upper Victoria Nile were attained at $35.4 \mathrm{~cm} \mathrm{FL} \mathrm{(Fig.} \mathrm{3)} \mathrm{and} 36.9 \mathrm{~cm} \mathrm{FL}$ (Fig. 4) respectively and were all found in the same class 

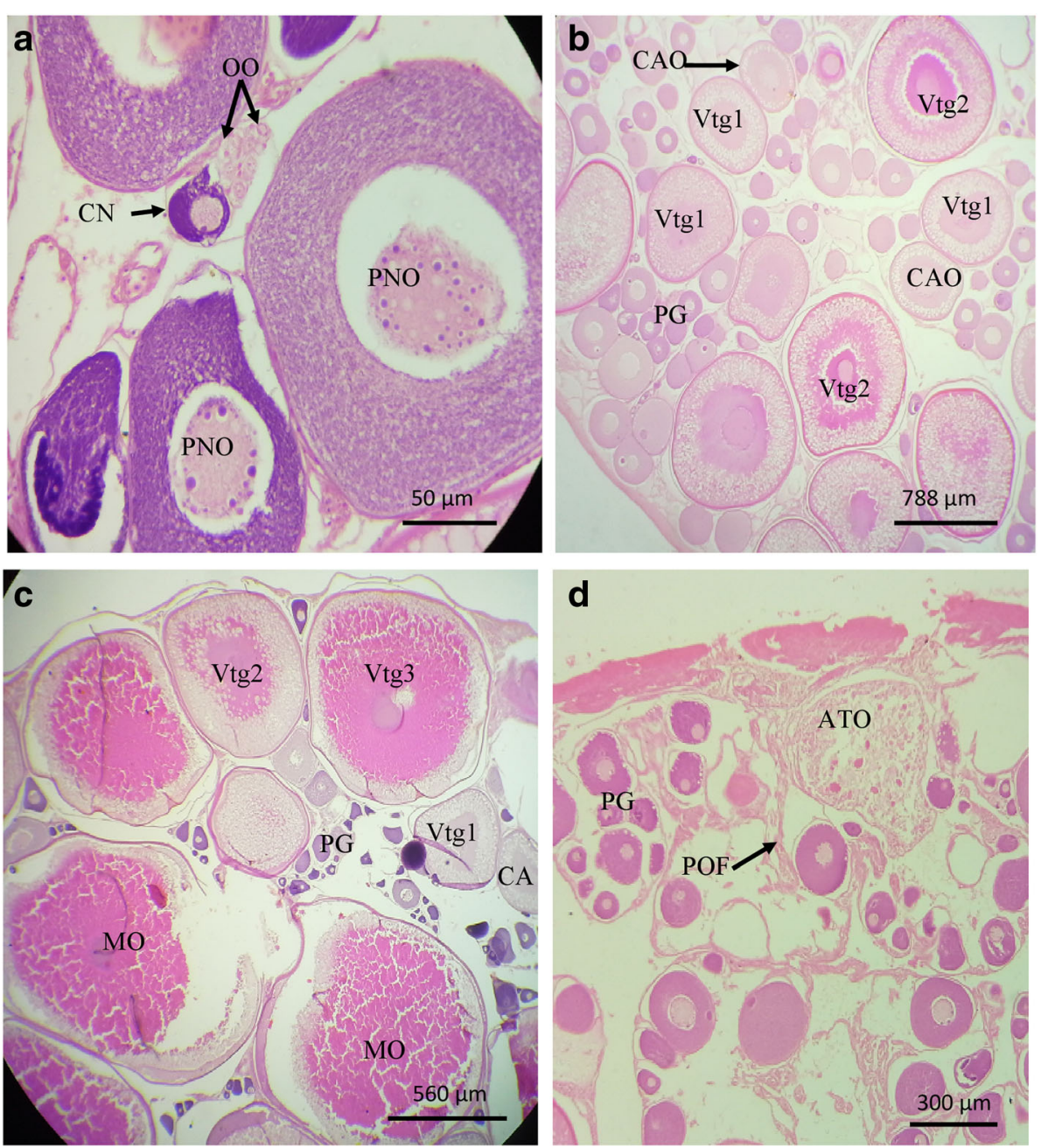

Fig. 1 Cross section of female gonad. a Stage I gonad with oogonia (OO), chromatin nucleolar oocytes (CN), and perinucleolar oocytes (PN). The three types constitute primary growth oocytes (PG). b Stage II gonads with cortical alveolar oocytes (CA), primary vitellogenic oocytes (Vtg1), and secondary vitellogenic oocytes (Vtg2). c Stage III constituted all other oocyte types with tertiary vitellogenic oocytes (Vtg3) and mature oocytes $(\mathrm{MO})$. d Stage $V$ with primary growth oocytes (PG), old post ovulatory follicles (POF), and degenerating atretic oocytes (AT). (H\&E)

Table 2 Measurements of B. altianalis oocytes for fish obtained from Lake Edward. Data are shown as mean \pm SD

\begin{tabular}{|c|c|c|c|c|c|c|}
\hline \multicolumn{7}{|c|}{ Lake Edward } \\
\hline No & Oocyte type & $\begin{array}{l}\text { Average cell size }(\mu \mathrm{m}) \\
\text { recorded for diameter }\end{array}$ & $\begin{array}{l}\text { Nucleus size }(\mu \mathrm{m}) \\
\text { recorded for diameter }\end{array}$ & $\begin{array}{l}\text { Estimated number of } \\
\text { nucleoli for each egg }\end{array}$ & $\begin{array}{l}\text { Ratio between oocyte } \\
\text { and nuclei sizes }\end{array}$ & $\begin{array}{l}\text { Total number of } \\
\text { oocytes measured }\end{array}$ \\
\hline \multirow[t]{4}{*}{1} & Primary growth oocytes & & & & & \\
\hline & Oogonia & $14.14 \pm 2.97$ & $9.21 \pm 1.76$ & - & $0.65 \pm 0.83$ & 194 \\
\hline & Chromatin nucleolar oocytes & $51.10 \pm 12.11$ & $22.14 \pm 5.10$ & $3.89 \pm 2.867$ & $0.44 \pm 0.10$ & 159 \\
\hline & Perinucleolar oocytes & $162 \pm 52.98$ & $72.76 \pm 27.13$ & $17.66 \pm 5.39$ & $0.42 \pm 0.13$ & 259 \\
\hline 2 & Cortical alveolar & $325.30 \pm 45.34$ & $122.75 \pm 29.11$ & $34.04 \pm 13.16$ & $0.38 \pm 0.08$ & 100 \\
\hline 3 & Vtg1 oocytes & $530.64 \pm 91.83$ & $125.47 \pm 37.35$ & $46.97 \pm 28.28$ & $0.24 \pm 08$ & 80 \\
\hline 4 & Vtg2 oocytes & $724.12 \pm 120.56$ & $166.81 \pm 51.00$ & $38.61 \pm 14.25$ & $0.22 \pm 0.06$ & 92 \\
\hline 5 & Vtg3 oocytes & $1046.21 \pm 397.41$ & $155.26 \pm 68.46$ & $38.6 \pm 13.35$ & $0.14 \pm 0.04$ & 111 \\
\hline 6 & Mature oocytes & $1510.67 \pm 182$ & $196.34 \pm 42.70$ & $26.14 \pm 13.40$ & $0.143 \pm 0.04$ & 85 \\
\hline
\end{tabular}


Table 3 Measurements of B. altianalis oocytes for fish obtained from Upper Victoria Nile; Data are shown as mean \pm SD

\begin{tabular}{|c|c|c|c|c|c|c|}
\hline \multicolumn{7}{|c|}{ River Nile } \\
\hline No & Oocyte type & $\begin{array}{l}\text { Average cell size }(\mu \mathrm{m}) \\
\text { recorded for diameter }\end{array}$ & $\begin{array}{l}\text { Nucleus size }(\mu \mathrm{m}) \\
\text { recorded for diameter }\end{array}$ & $\begin{array}{l}\text { Estimated number of } \\
\text { nucleoli for each egg }\end{array}$ & $\begin{array}{l}\text { Ratio between oocyte } \\
\text { and nuclei sizes }\end{array}$ & $\begin{array}{l}\text { Total number of } \\
\text { oocytes measured }\end{array}$ \\
\hline \multirow[t]{4}{*}{1} & Primary growth oocyte & & & & & \\
\hline & Oogonia & $13.95 \pm 2.97$ & $9.40 \pm 1.82$ & - & $0.64 \pm 0.10$ & 168 \\
\hline & Chromatin nucleolar & $48.85 \pm 10.47$ & $21.23 \pm 4.36$ & $1.81 \pm 1.17$ & $0.44 \pm 0.10$ & 175 \\
\hline & Perinucleolar oocytes & $162 \pm 64.82$ & $67.40 \pm 36.90$ & $16.84 \pm 7.94$ & $0.32 \pm 0.13$ & 364 \\
\hline 2 & Cortical alveolar & $330.63 \pm 62.75$ & $121.93 \pm 28.23$ & $31.40 \pm 9.43$ & $0.37 \pm 0.76$ & 134 \\
\hline 3 & Vtg1 oocytes & $502.88 \pm 114.97$ & $124.04 \pm 0.34$ & $28.82 \pm 9.23$ & $0.27 \pm 0.07$ & 102 \\
\hline 4 & Vtg2 oocytes & $767.40 \pm 124.08$ & $154.02 \pm 46.16$ & $29.67 \pm 12.06$ & $0.21 \pm 0.07$ & 96 \\
\hline 5 & Vtg3 oocytes & $1036.60 \pm 286.93$ & $160.56 \pm 0.042$ & $21.90 \pm 9.37$ & $0.15 \pm 0.044$ & 82 \\
\hline 6 & Mature oocytes & $1540.05 \pm 184.68$ & $204.31 \pm 76.34$ & $22.32 \pm 15.30$ & $0.135 \pm 0.04$ & 80 \\
\hline
\end{tabular}

size of 35-39.9 cm FL. Similarly, the $\mathrm{L}_{50}$ for males from Lake Edward and Upper Victoria Nile were attained in the same class size of $20-24.9 \mathrm{~cm}$ FL. Males in Lake Edward attained their maturity at $21.1 \mathrm{~cm}$ FL (Fig. 3) while those from River Nile attained their $\mathrm{L}_{50}$ at $22.9 \mathrm{~cm}$

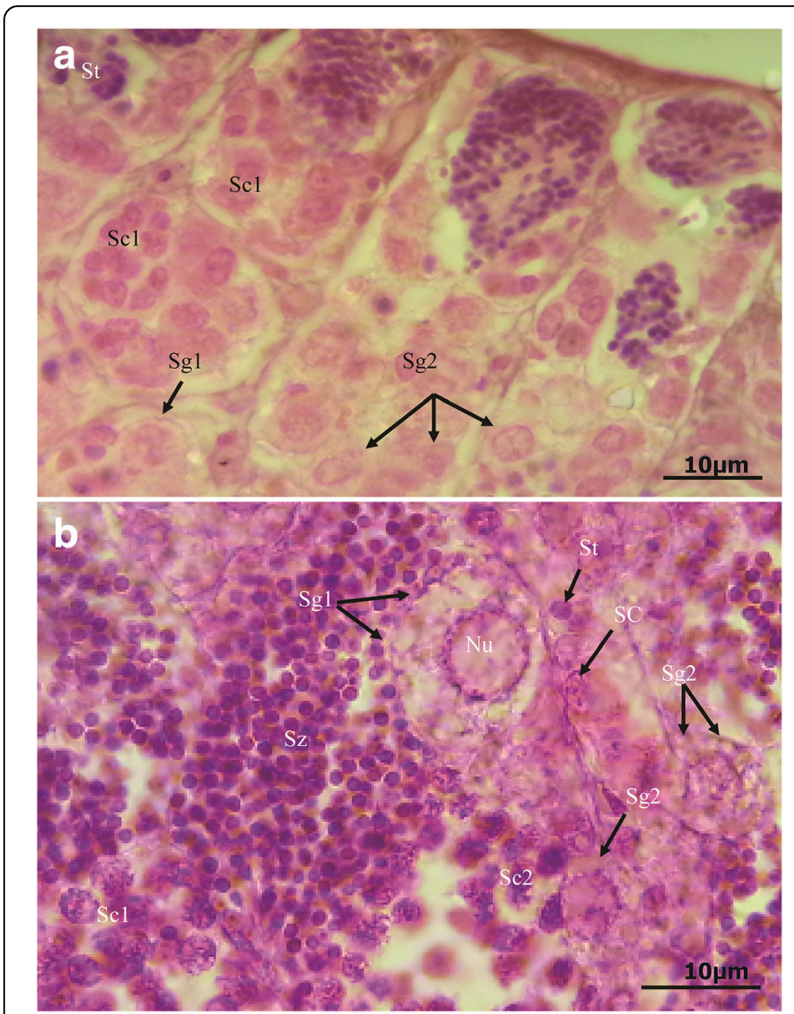

Fig. 2 A cross section of testis showing spermatogenic cells at different stages. a Stage II testis dominated by primary spermatocytes (Sc1) but fewer spermatids and spermatozoans (Sz) are observed. $\mathbf{b}$ Stage III testis with all the types of spermatogenic cells that include primary spermatogonia (Sg1) with a large nucleus $(\mathrm{Nu})$, secondary spermatogonia ( $\mathrm{Sg} 2)$, primary spermatocytes $(\mathrm{Sc} 1)$, secondary spermatocytes (Sc2), and spermatids (St). The stage is dominated by spermatozoa (Sz). The sertoli cell (SC) is also observed. (H\&E)
FL (Fig. 4). Generally, males from both water bodies attained their $L_{50}$ much earlier (smaller size) than the females. The $\mathrm{L}_{50}$ at standard length SL and total length TL are also provided in Table 6. The smallest mature female caught from Lake Edward was $22.6 \mathrm{~cm}$ FL while the smallest mature male was $18.2 \mathrm{~cm}$ FL. The biggest female caught from Lake Edward was $89.5 \mathrm{~cm}$ FL (100 TL) while the biggest male was $73.2 \mathrm{~cm} \mathrm{FL}(82.2 \mathrm{~cm}$ TL). All males above $37.9 \mathrm{~cm}$ FL were mature and all females above $47.7 \mathrm{~cm}$ FL were mature. Smallest mature female from Upper Victoria Nile was $24.6 \mathrm{~cm}$ FL while the biggest fish caught was $77.0 \mathrm{~cm}$ FL $(83.0 \mathrm{~cm} \mathrm{TL})$. The smallest male caught was $14.5 \mathrm{~cm}$ FL while the biggest male caught was $66.2 \mathrm{~cm}$ FL $(70 \mathrm{~cm} \mathrm{TL})$. All females above $52.7 \mathrm{~cm}$ FL were mature and all males above $37.6 \mathrm{~cm}$ FL were mature.

\section{Length-weight relationships}

There was a strong and positive correlation between length and weight $(r \geq 0.90)$ for both individuals from Lake Edward and Upper Victoria Nile (Table 6). The weights corresponding to $\mathrm{L}_{50}$ (SL, FL, and TL) were estimated by the power equations at each length (Table 6). The power equation value of " $b$ " was $\geq 3.100$ for both females and males from Lake Edward and Upper Victoria Nile which was significantly higher than the value of $b=$ 3, as determined by Froese (2006) (Table 6).

\section{Size frequency distribution (distribution of number of sampled fish in class size)}

Size frequency distributions of females and males in Lake Edward followed the same pattern, with the highest number of fish recorded in 25-29.9 cm FL class size for both sexes and gradually declining in other class sizes (Fig. 5). The variations shown for males and females from Upper Victoria Nile did not follow a same pattern as those from Lake Edward (Fig. 6). The males were 
Table 4 Classification of maturity stages for males B. altianalis

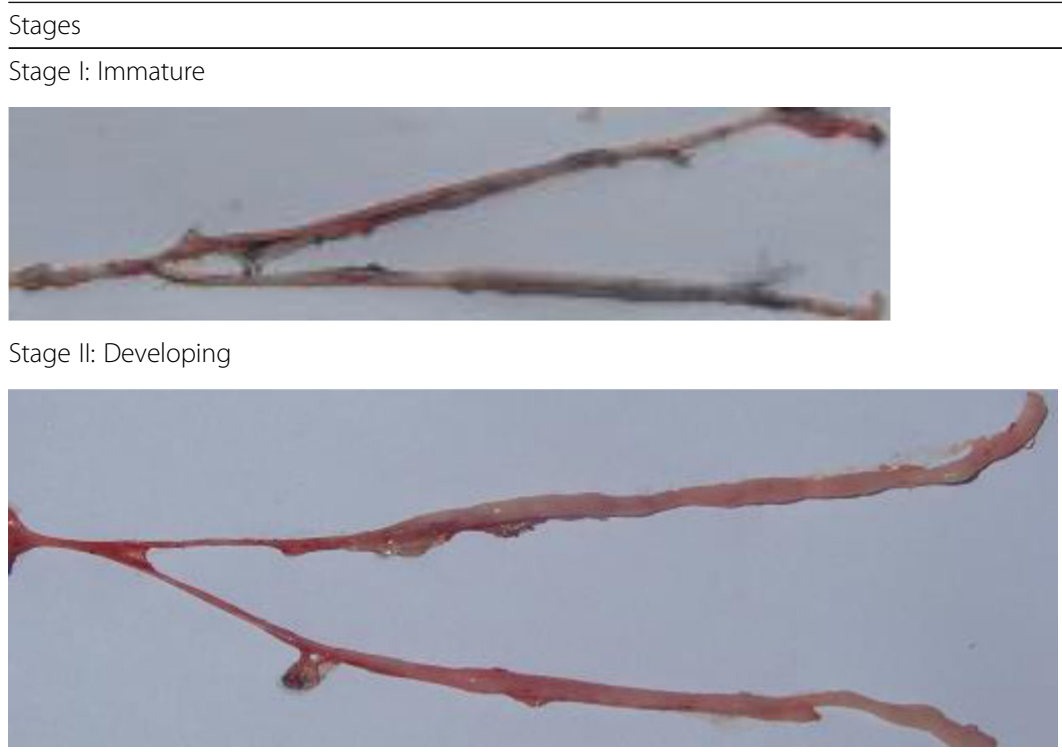

Stage III: Spawning capable

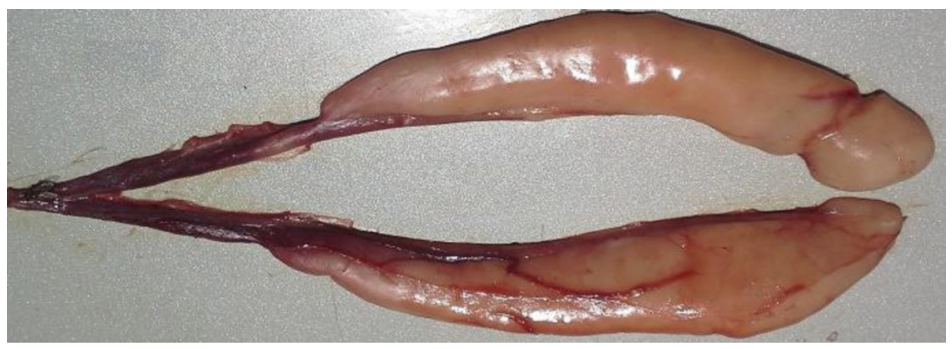

Stage IV: Regressed

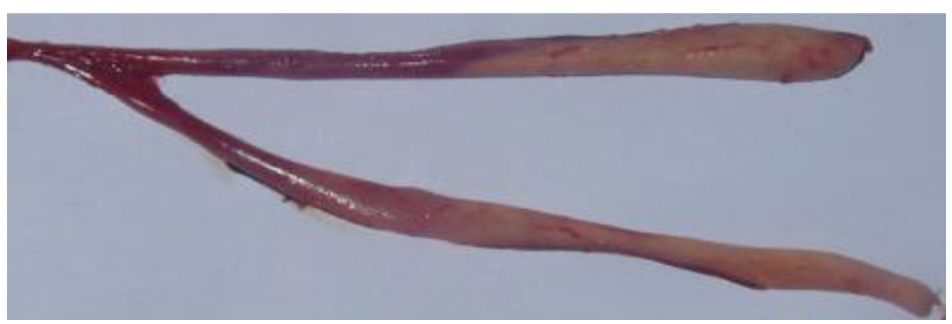

Stage V: Regenerating

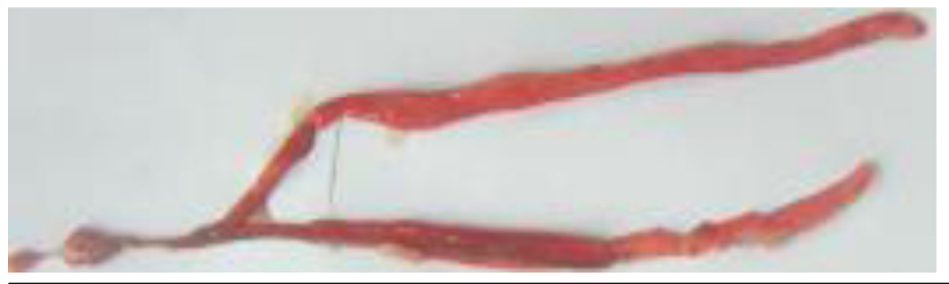

Description

Strand-like Y-shaped gonad and transparent. This stage is dominated by spermatogonia only

Easily distinguishable as males and off-white colored gonads. The majority of the cells are spermatogonia, and spermatocytes but occasionally few groups of spermatids and very few spermatozoa are observed
Large gonads, off-white coloration; dominated by lobules filled with spermatozoa
Reduced in size with bloody perches. Other portions still look off-white. Microscopically they are large empty spaces with residual spermatozoa. However other portions may still have some viable spermatozoa. more frequent in class size of $30-34.9 \mathrm{~cm}$ to $45-$ $49.9 \mathrm{~cm} \mathrm{FL}$ and there after they declined. The highest peak for females was obtained in a class size of 55$59.9 \mathrm{~cm}$ FL. The males from both water bodies were conspicuously absent or very few in upper class sizes above 60-64.5 cm FL compared to females. For the females from Upper Victoria Nile, high frequencies were noted in upper class sizes while males almost disappeared (Fig. 6).

\section{Discussion}

The availability of quality and sufficient seed is the cornerstone for the successful commercialization of domesticated fish species (George et al. 2010; Mair
Further reduced in size with pale reddish coloration. This stage largely contains parked spermatogonia with reduced spaces containing very few residual spermatozoa. 
Table 5 Spermatogenic cell measurements in B. altianalis. Data are shown as mean \pm SD

\begin{tabular}{llllll}
\hline Cell type & & Lake Edward $(\mu \mathrm{m})$ & Upper Victoria Nile $(\mu \mathrm{m})$ & Average size for both water bodies & $t$-test $(p=0.05)$ \\
\hline Spermatozoa & Cell size & $2.09 \pm 0.23^{\mathrm{a}}$ & $2.12 \pm 0.23^{\mathrm{a}}$ & $2.10 \pm 0.23$ & $t_{403}=-1.08$ \\
Spermatids & Cell size & $2.31 \pm 0.33^{\mathrm{a}}$ & $2.78 \pm 0.60^{\mathrm{b}}$ & $2.49 \pm 0.51$ & $t_{211.57}=-8.914$ \\
Secondary spermatocyte & Cell size & $3.14 \pm 0.45^{\mathrm{a}}$ & $4.13 \pm 0.93^{\mathrm{b}}$ & $3.57 \pm 0.86$ & $t_{293.07}=-14.66$ \\
Primary spermatocyte & Cell size & $4.76 \pm 0.62^{\mathrm{a}}$ & $5.47 \pm 0.82^{\mathrm{b}}$ & $5.00 \pm 0.78$ & $t_{237.74}=-9.21$ \\
Secondary spermatogonia & Cell size & $7.90 \pm 1.55^{\mathrm{a}}$ & $8.63 \pm 2.35^{\mathrm{b}}$ & $8.28 \pm 2.03$ & $t_{328}=-3.495$ \\
& Nucleus & $6.12 \pm 1.12^{\mathrm{a}}$ & $7.09 \pm 1.65^{\mathrm{b}}$ & $6.61 \pm 1.50$ & $t_{371}=-6.720$ \\
Primary spermatogonia & Cell size & $12.44 \pm 1.53^{\mathrm{a}}$ & $13.97 \pm 1.71^{\mathrm{b}}$ & $13.26 \pm 1.26$ & $t_{393.08}=-9.55$ \\
& Nucleus & $8.48 \pm 1.17^{\mathrm{a}}$ & $10.40 \pm 1.78^{\mathrm{b}}$ & $9.51 \pm 1.82$ & $t_{371.73}=-12.72$ \\
\hline
\end{tabular}

Different subscripts $a, b$ across rows indicate significant differences

2002). The seed is a reflection of a healthy and quality broodstock that will eventually determine the availability of quality seed for commercial production of the species. In a number of cultured species, the brood fish is an integral process of a well-planned seed production system (Bondad-Reantaso 2007). One of the key characteristics of the spawning technology is the appropriate size and the source as well as availability of both broodstock females and males. The wild sources are still the most significant sources of the broodstock for newly domesticated fish and grading up of genetically depressed captive stocks. In this study, sex distribution from Lake Edward and Upper Victoria Nile were found to be the same, thus the sex ratios of females to males were similar in both water bodies. The ratios were skewed toward more females. Skewed sex ratios could suggest some migratory activity related to breeding seasons (Mahmood et al. 2011), a shorter life span for males, a natural intrinsic characteristic for biased sexes, or environmental variations (Baroiller et al. 2009; Vandeputte and Quillet 2012). In spite of the fact that samples were peaked in a dry month of February and wet months of March and April, a biased sex ratio was observed. Therefore, it seems that sex ratio bias toward females is genetically predisposed. Nevertheless, the occurrence of males and females at the same sampling points suggested that it is much easier for the farmer to collect both males and females for breeding (Aruho et al. 2013).

This study observed that the general developmental and maturation process in $B$. altianalis was similar to that described in other cyprinid species (Booth and Weyl 2000; Lone and Hussain 2009; Maack and Segner 2003;

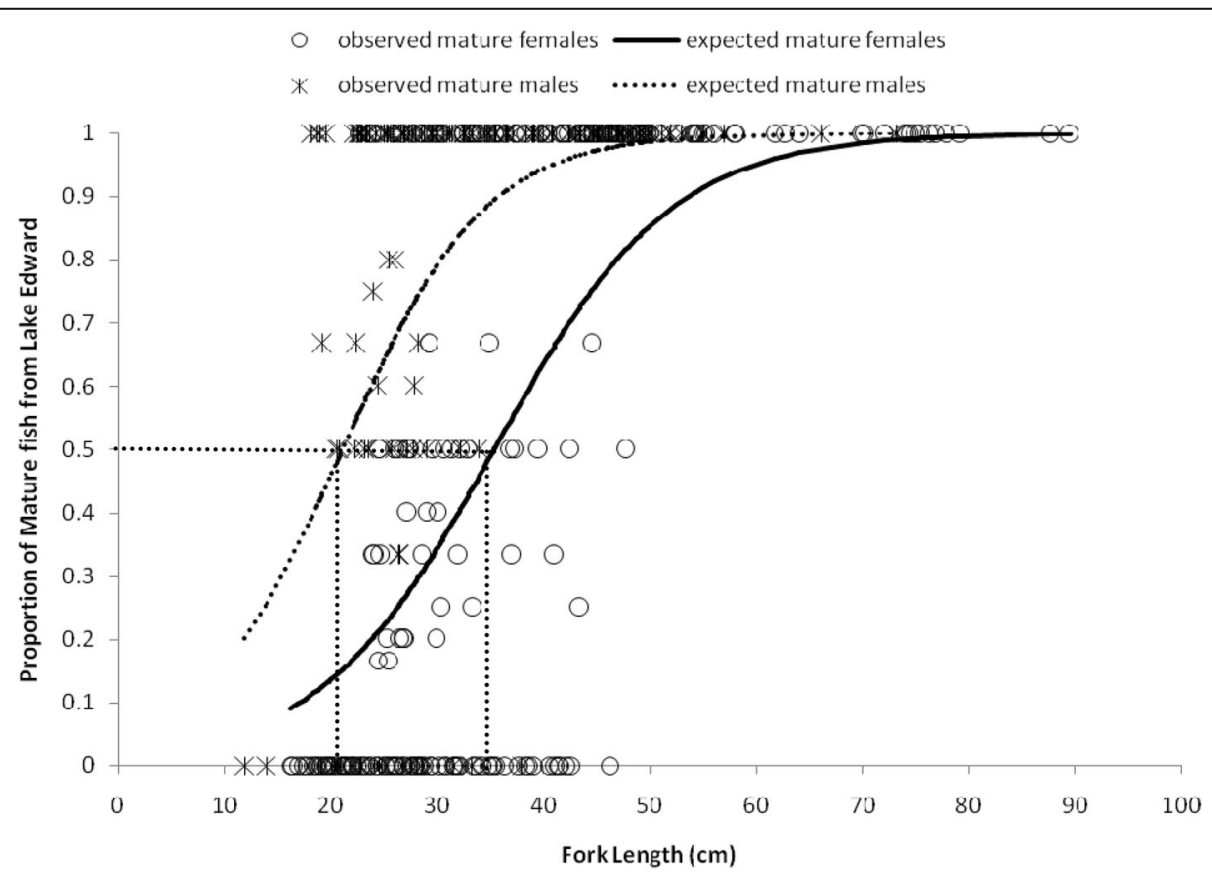

Fig. 3 Maturity ogives for male and female B. altianalis sampled from Lake Edward in 2015. Ogive is fitted to estimate length at maturity $L_{50}$ in females and males represented by dotted lines 
- observed mature females _—expected mature females

$\times$ observed mature males ........ expected mature males

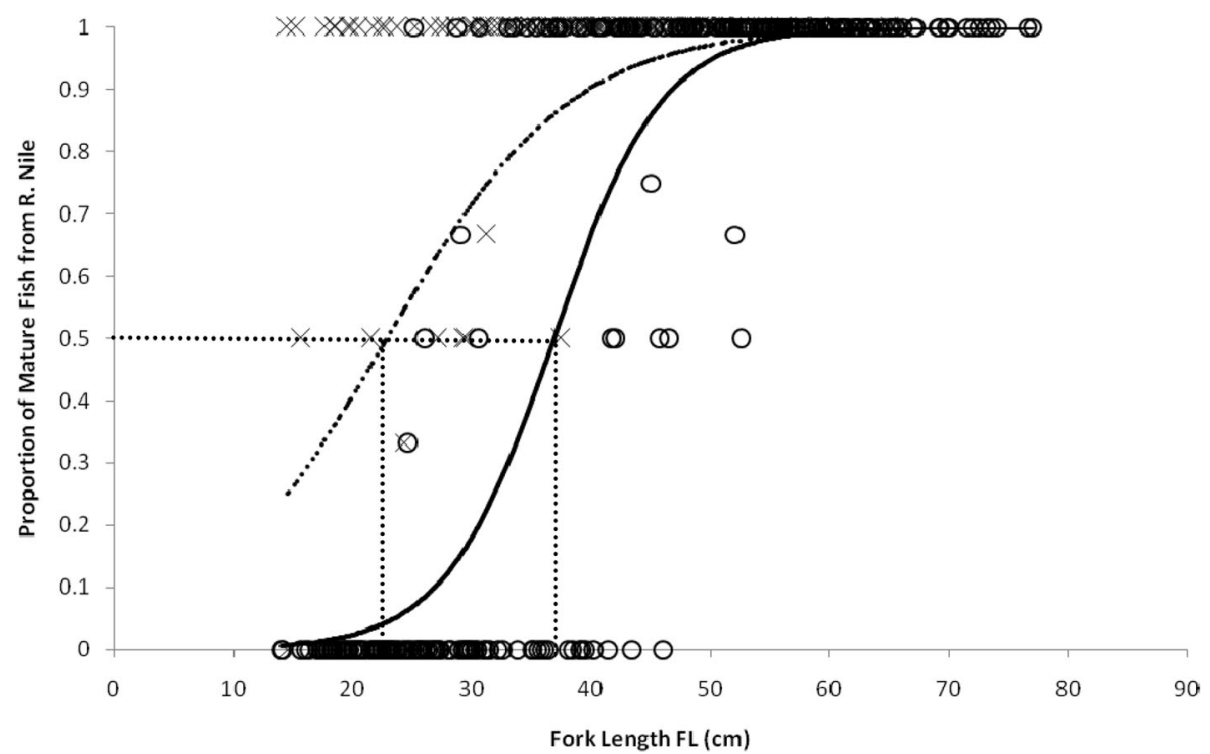

Fig. 4 Maturity ogives for male and female B. altianalis sampled from Victoria Nile in 2015. Ogive is fitted to estimate length at maturity $L_{50}$ in females and males represented by dotted lines

Table 6 Sexual maturity and length-weight relationships for B. altianalis from Lake Edward and Upper Victoria Nile

\begin{tabular}{|c|c|c|c|c|}
\hline \multirow{2}{*}{$\begin{array}{l}\text { Parameters at } \\
L_{50}\end{array}$} & \multicolumn{2}{|l|}{ Lake Edward } & \multicolumn{2}{|l|}{ Upper River Nile } \\
\hline & Females & Males & Females & Males \\
\hline \multicolumn{5}{|c|}{ Standard length (SL) } \\
\hline Class size & $30-34.9$ & $15-19.9$ & $30-34.9$ & $15-19.9$ \\
\hline $\mathrm{SL}(\mathrm{cm})$ & 31.9 & 18.0 & 33.1 & 19.1 \\
\hline$W(\mathrm{~g})=a S L^{b}$ & $W=0.014 S L^{3.116}$ & $W=0.020 S L^{3.130}$ & $W=0.013 S L^{3.153}$ & $W=0.013 S L^{3.150}$ \\
\hline$W(g)$ & 627.4 & 127.2 & 716.8 & 141.4 \\
\hline$r$ & 0.923 & 0.908 & 0.940 & 0.931 \\
\hline$r^{2}$ & 0.978 & 0.972 & 0.991 & 0.984 \\
\hline \multicolumn{5}{|l|}{ Fork length (FL) } \\
\hline Class size & $35-39.9$ & $20-24.9$ & $35-39.9$ & $20-24.9$ \\
\hline $\mathrm{FL}(\mathrm{cm})$ & 35.4 & 21.1 & 36.9 & 22.9 \\
\hline$W(\mathrm{~g})=a \mathrm{FL}^{b}$ & $W=0.01 \mathrm{FL}^{3.129}$ & $W=0.010 \mathrm{FL}^{3.128}$ & $W=0.008 \mathrm{FL}^{3.164}$ & $W=0.010^{3.126}$ \\
\hline$W(\mathrm{~g})$ & 702.8 & 135.8 & 726.4 & 178.7 \\
\hline$r$ & 0.925 & 0.915 & 0.939 & 0.930 \\
\hline$r^{2}$ & 0.976 & 0.979 & 0.910 & 0.984 \\
\hline \multicolumn{5}{|c|}{ Total length (TL) } \\
\hline Class size & $40-45.9$ & $20-24.9$ & $40-44.9$ & $20-24.9$ \\
\hline $\mathrm{TL}(\mathrm{cm})$ & 41.6 & 23.5 & 40.0 & 24.2 \\
\hline$W(\mathrm{~g})=a T L^{b}$ & $W=0.006 \mathrm{TL}^{3.160}$ & $W=0.006 \mathrm{TL}^{3.149}$ & $W=0.004 \mathrm{TL}^{3.281}$ & $W=0.004 \mathrm{TL}^{3.251}$ \\
\hline$W(\mathrm{~g})$ & 784.0 & 124.6 & 726.4 & 126.10 \\
\hline r & 0.926 & 0.911 & 0.933 & 0.921 \\
\hline$r^{2}$ & 0.973 & 0.965 & 0.989 & 0.980 \\
\hline
\end{tabular}


¿ Females-Lake Edward Males - Lake Edward

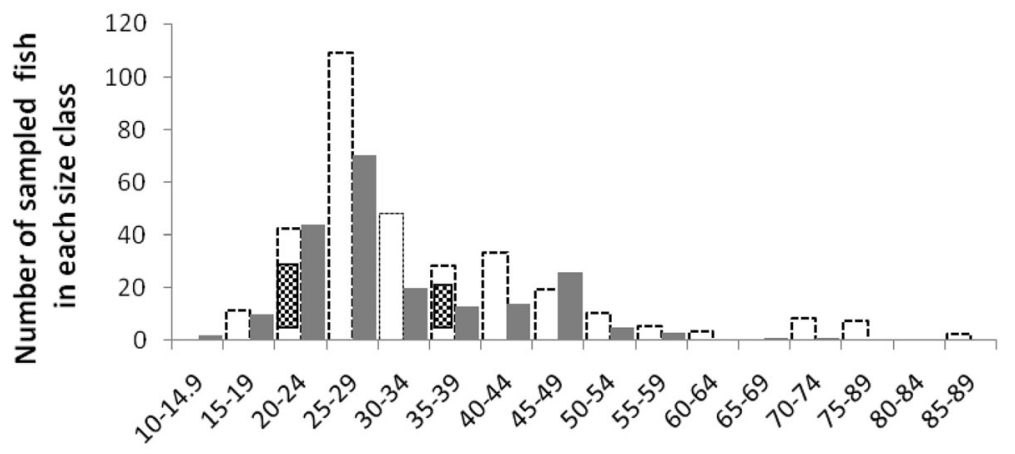

Fork Length $(\mathrm{cm})$

Fig. 5 Length-frequency distribution of B. altianalis from Lake Edward. Bars with shaded textboxes in the middle indicate the class size with $L_{50}$

Smith and Walker 2004). However, special specific processes including the color and size of gonads, oocytes, and spermatogenic cells, the location of the nucleus, and number of nuclei may vary for each species and were inevitably described to ensure a clear guided description for identification of classification staging as suggested by Brown-Peterson et al. (2011). Although size variations were only noted with spermatogonia, spermatocytes, and spermatids among the two populations, the final spermatozoa sizes emerging from the cysts during spermiation process were the same, attributing the variations to differences in cytoplasmic volume. As observed with spermatozoa, there were no differences in oocyte sizes between the two populations from both water bodies. However, a study by Muwanika et al. (2012) suggested that morphological and genetical differences occurred between the two population clusters but did not identify them as different morphs or species and recommended further investigations because the sample size was small and required robust genetic methods. Based on the current results, it seems the two populations remain the same with less divergent strategies or rather still "primitive" in its evolutionary process. Slight differences observed in cytoplasic volume between the two populations could be linked to localized environmental conditions for each water body. Localized changes in the water environment, preferential food requirements, or fishing pressure may account for the observed differences (Lam 1983). Genetic studies are required to help ascertain if the differences between these groups exist. However, since no significant differences in oocytes and spermatozoa were observed between the two populations, the same classification (staging) was maintained for B. altianalis from both water bodies for description of length at maturity. This is important for guiding farmers and other fisheries scientists in staging $B$. altianalis gonads.

Results from this study showed that the size at maturity $\mathrm{L}_{50}$ for $B$. altianalis males from Upper Victoria Nile and from Lake Edward were obtained in the same class size as was for females. This finding further suggests that

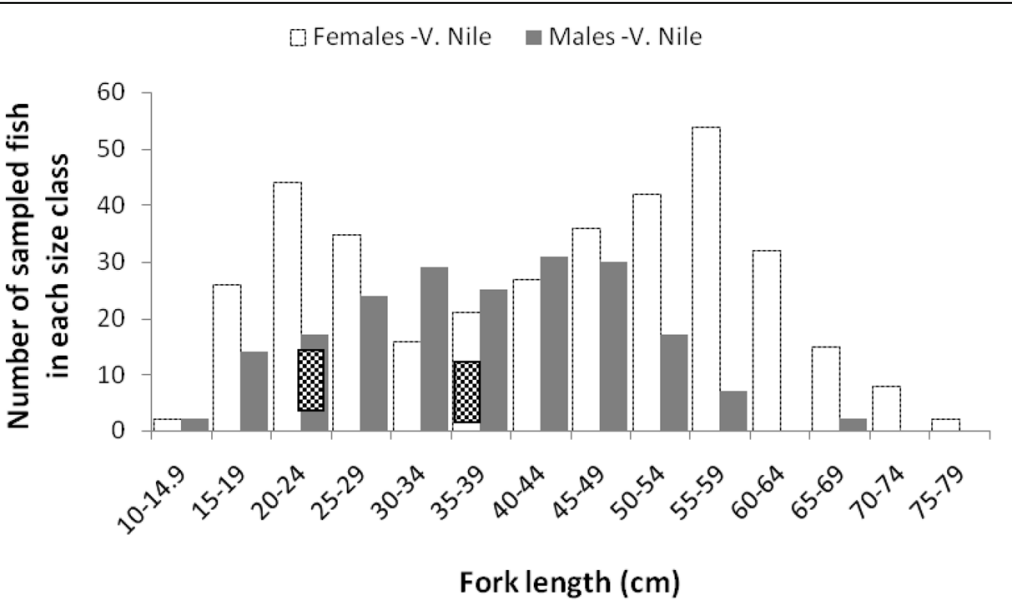

Fig. 6 Length-frequency distribution of B. altianalis from Victoria Nile. Bars with shaded textboxes in the middle indicate the class size with $L_{50}$ 
in spite of two water bodies being separated or having no close connection the species has not separated into other morphs or forms. Despite the fact that they were in the same class size, the $\mathrm{L}_{50}$ values were not exactly of the same length. In species such as Oreochromis niloticus (Duponchelle and Panfili 1998), Peritalbagrus fulvidraco (Cao et al. 2009), and Hippoglossoides platessoides (Morgan and Colbourne 1999), the variations observed in $\mathrm{L}_{50}$ in their population cohorts in different sampling areas were attributed to fishing pressure and environmental differences (phenotypic plasticity) other than genetic differences. Therefore, the minor differences in $\mathrm{L}_{50}$ observed in $B$. altianalis were probably linked to environmental differences other than genetic variations. It seems $B$. altianalis still retains very primitive traits with longer evolutionary characteristics and thus fish from Lake Edward and Upper Victoria Nile could easily be crossbred to obtain the best traits possible for culture. The study also revealed that males matured much earlier than females. Early maturation of males ensures that all eggs produced by females are fertilized during spawning (Aruho 2017).

The selection of an appropriate broodfish for spawning is largely linked to knowledge of maturation size and takes into cognizance of conservation of the wild stocks to avoid over exploitation. For instance size frequency distribution noted in this study suggests that the $50 \%$ of the sampled population $\left(\mathrm{L}_{50}\right)$ for $B$. altianalis males from Lake Edward and Upper Victoria Nile obtained in a class size of $20-24.9 \mathrm{~cm}$ FL $(135.8 \mathrm{~g}-178.7 \mathrm{~g})$ was smaller than the minimum legally recommended sizes of 30-34.9 cm FL (about $500 \mathrm{~g}$ ). The recommended fishing nets for catching this size is $\geq 4.5$ in. mesh size (amendment Fish Act, 1951). This implied that any size below $30-34.9 \mathrm{~cm}$ FL is not legally acceptable for harvesting as broodfish. Secondly, in spite of the fact that the noted $\mathrm{L}_{50}$ could appropriately be collected for spawning, the weight is rather small for handling in order to obtain milt and also not appropriate for selection of good breeds. Hence, this study suggests that males for breeding fish could appropriately be picked from class size of $\geq 30-34.9 \mathrm{~cm}$ FL (417-675 g) for males and $\geq 35$ $39.9 \mathrm{~cm}$ FL (700-726.4 g) for females.

The study showed that males and females from Lake Edward were more frequent in a class size of 25$29.9 \mathrm{~cm}$ FL than in other class sizes suggesting an improved enforcement effort of fishing regulations for the right net sizes on the lake. The reduction thereafter implied fishing effort or activity. The pattern of females and males in Upper Victoria Nile did not suggest a relationship with fishing activity. The frequency of females was notably high in the class sizes of $15-19.9$ to $25-$ $29.9 \mathrm{~cm} \mathrm{FL}$ and from $40-44.9$ to $60-64.9 \mathrm{~cm}$ FL, while the male frequencies were high between $30-34.9$ and
45-49.9 cm FL. This implied that there was little fishing pressure. There is a reported regular interruption of power generating activities at Kira and Bujagali power Dams that bars fishers from fishing daily and some portions are restricted and inaccessible by fishermen (personal communication with fishers; David Odong, head of fishermen at Kiira landing site). This could further explain why the $L_{50}$ values for fish from Upper Victoria Nile were slightly higher than those from Lake Edward for both females and males. Hence, sustained fishing pressure of $B$. altinalis is more likely to influence evolutionary changes in $\mathrm{L}_{50}$ for Lake Edward individuals first before those from Upper Victoria Nile. Sustained selective fishing pressure has been suggested to cause rapid changes in evolution of maturation schedules in many fish species (Audzijonyte et al. 2013; Hunter et al. 2015; Law 2000). The frequency distribution and the $L_{50}$ observed in $B$. altianalis from this study showed that very few or no males were caught above $65 \mathrm{~cm}$ FL. In some fish species, shorter male life spans were associated with aggressive behavior of males making them vulnerable to enemies during feeding or mating (King et al. 2013; Reichard et al. 2014). However, further investigations are necessary to ascertain if there is any behavior that makes B. altianalis susceptible to predators or fishing.

The coefficient " $b$ " of the power curves obtained for the weight-length relationship of the sampled population suggested that natural growth rates were similar for both populations from Lake Edward and Upper Victoria Nile because all the " $b$ " values were in the same range of 3.126-3.164 for both males and females. This was also reported by Ondhoro et al. (2016) for the same species. These values were significantly higher than $b=3$ (Froese 2006) implying that the fish girth increased much faster than the length (Froese 2006; Karachle and Stergiou 2012). Therefore, B. altianalis from Lake Edward and Upper Victoria Nile were accurately grouped under species with positively allometric growth. The weightlength power equation had a strong $r^{2}$ of $>97 \%$; hence, the weights at each $\mathrm{L}_{50}$ were and can be accurately estimated using the power equations obtained in this study.

The farm records for the cultured B. altianalis (Additional file 1) also indicated that males matured at smaller sizes than females as in the wild populations. In spite of the fact that $L_{50}$ was not determined for the farm record samples because of the very small numbers, the fewer number of fish from the records show that both females and males matured at smaller sizes compared to their counterparts in the wild. This is common with many cultured species, and it is a strategy by the fish to ensure earlier production of offsprings under confined and or unpredictable environmental conditions (Brummett 1995; Longalong et al. 1999). It is imperative though to use bigger males ( $\geq 30-34.9 \mathrm{~cm} \mathrm{FL})$ as earlier 
suggested, than the indicated sizes for easier selection of good broodstock. However, a thorough experimental study is recommended for determination of appropriate values of $L_{50}$ in ponds with appropriate feed.

\section{Conclusions}

Evidence obtained from sex ratios, $\mathrm{L}_{50}$, power equations, and germ cell sizes in this study indicated that $B$. altianalis males and females from Lake Edward were similar to those from Upper Victoria Nile; hence, there are no clear evolutionary lines detected for this species and the species has remained more or less primitive. The species could therefore be crossbred where applicable for the best cultured traits. The length at which $50 \%$ individuals were mature was $20-24.9 \mathrm{~cm}$ FL for males and $35-39.9 \mathrm{~cm}$ FL for females. But because of the need to strict adherence to fishing regulations and conservation of the wild resources as well as the need to have selection of good broodfish, the study recommends selecting individuals from 30 to $34.9 \mathrm{~cm}$ FL for males and 35 to $39.9 \mathrm{~cm}$ FL for females to be included in the spawning protocol. These individuals could be picked from the same areas for breeding and during the periods when breeding fish are prominent (Rutaisire et al. 2015). Because the famed fish attained smaller sizes at maturity than their wild counterparts, this may point to the fact that more growth study experiments with appropriate conditions and diet could be required to improve the growth performance of $B$. altianalis.

\section{Additional file}

Additional file 1: Table S1. Annual female and male percentage ages of ripe individuals between 2012 and 2014; Stocked in January 2012; Data are shown as mean \pm SD (source: Ssenya fish farm, Lengo-Masaka). Data was obtained from Ssenya fish farm and it describes the size of fish and the period when fish began to show sexual maturity during growth in ponds at the farm. (DOC $32 \mathrm{~kb}$ )

\section{Abbreviations}

ANOVA: Analysis of variance; ATAAS: Agriculture Technology Development and Advisory Services project; COVAB: College of Veterinary Medicine, Animal Resources and Bio-security; FL: Fork length; $L_{50}$ : Length at sexual maturity; NARO: National Agriculture Research Organization; SL: Standard length; TL: Total length

\section{Acknowledgements}

We acknowledge Mr. Waiswa and Mandela from Katwe landing site on Lake Edward and Mr. Odong of Jinja town who organized and guided us in collection of samples on the Lake Edward and River Nile. We thank Mr. Magidu Kiseka of College of Veterinary Medicine, Animal Resources and Bio-security for having organized for us the laboratory and equipment we used in histological processing of samples. We also thank the Ssenya fish farm for providing us with the pond data they had recorded on growth of B. altianalis.

\section{Funding}

We are grateful for the financial support from the Agriculture Technology Development and Advisory Services project (ATAAS), funded by the Government of Uganda (Uganda/AFRICA- P109224) through a facility by the World Bank implemented by National Agriculture Research Organization (NARO).

\section{Availability of data and materials}

Publishable data have been provided in the main manuscript, and a table has been provided as an additional. However, additional raw data and data analysis sheets will be provided on request through authors' email.

\section{Authors' contributions}

AC initiated the idea, participated in data collection, and participated in data analysis and writing of the manuscript. RD and OOC participated in data collection, literature search, and manuscript drafting. WK participated a lot in data analysis and improving the manuscript language editing. Professors FB and JR supervised the data collection process, provided technical and professional guidance, assisted in refinement, and improved the quality of the paper. All authors read and approved the final manuscript.

\section{Ethics approval}

Freshly killed fish samples were caught using fishing methods approved in Uganda's Fish Act, 1964.

\section{Consent for publication}

Consent was obtained from Ssenya fish farm to analyze and publish the farm records on growth of $B$. altianalis.

\section{Competing interests}

The authors declare that they have no competing interests.

\section{Publisher's Note}

Springer Nature remains neutral with regard to jurisdictional claims in published maps and institutional affiliations.

\section{Author details}

'Aquaculture Research and Development Center, Kajjansi, PO Box 530, Kampala, Uganda. ${ }^{2}$ Kyegegwa District Local Government, P.O Box 99, Kyegegwa, Uganda. ${ }^{3}$ National Fisheries Resources Research Institute, POBox 343, Jinja, Uganda. ${ }^{4}$ Buginyanya Zonal Agricultural Research and Development Institute, P.O Box 1356, Mbale, Uganda. ${ }^{5}$ College of Natural Sciences, Department of Biological Science, Makerere University, P.O. Box 7062, Kampala, Uganda. ${ }^{6}$ National Agricultural Research Organization, P.O. Box 295, Entebbe, Uganda.

Received: 11 June 2018 Accepted: 31 August 2018

Published online: 12 November 2018

\section{References}

Aruho C. Optimizing spawning and growth performance of larvae and juveniles in Barbus altianalis (boulenger, 1900) (PhD thesis, Makerere University). 2017; 243pp.

Aruho C, Basiita RK, Kahwa D, Bwanika G, Rutaisire J. Reproductive biology of Bagrus docmak in the Victoria Nile, Uganda. Afr J Aquat Sci. 2013;38(3):26371. https://doi.org/10.2989/16085914.2013.807972.

Audzijonyte A, Kuparinen A, Fulton EA. How fast is fisheries-induced evolution? Quantitative analysis of modelling and empirical studies. Evol Appl. 2013;6(4): 585-95. https://doi.org/10.1111/eva.12044.

Bancroft JD, Gamble M. Theory and practice of histological techniques. 5th ed. Edinburgh: Churchill Livingston Publishers; 2002. p. 85-107.

Baroiller JF, D'Cotta H, Saillant E. Environmental effects on fish sex determination and differentiation. Sex Dev. 2009;3:118-35. https://doi.org/10.1159/ 000223077.

Basiita RK, Aruho C, Kahwa D, Nyatia E, Bugenyi FW, Rutaisire J. Differentiated gonochorism in Nile perch Lates niloticus from Lake Victoria, Uganda. Afr J Aquat Sci. 2011;36(1):89-96. https://doi.org/10.2989/16085914.2011.559694.

Bondad-Reantaso MG. Assessment of freshwater fish seed resources for sustainable aquaculture. Fisheries Technical paper no. 501. Rome: FAO; 2007. p. 628.

Booth AJ. On the life history of the lesser gurnard (Scorpaeniformes: Triglidae) inhabiting the Agulhas Bank, South Africa. J Fish Biol. 1997;51:1155-73. https://doi.org/10.1111/j.1095-8649.1997.tb01133.x.

Booth AJ, Weyl OL. Histological validation of gonadal macroscopic staging criteria for Labeo cylindricus (Pisces: Cyprinidae). Afr Zool. 2000;35(2):223-31.

Brown-Peterson NJ, Wyanski DM, Saborido-Rey F, Macewicz BJ, Lowerre-Barbieri SK. A standardized terminology for describing reproductive development in fishes. Mar Coast Fish. 2011;3(1):52-70. 
Brummett RE. Environmental regulation of sexual maturation and reproduction in tilapia. Rev Fish Sci. 1995;3(3):231-48. https://doi.org/10.1080/ 10641269509388573.

Cao L, Song B, Zha J, Yang C, Gong X, Li J, Wang W. Age composition, growth, and reproductive biology of yellow catfish (Peltobagrus fulvidraco, Bagridae) in Ce Lake of Hubei Province, Central China. Environ Biol Fish. 2009;86:75-88. https://doi.org/10.1007/s10641-008-9342-x.

Duponchelle F, Panfili J. Variations in age and size at maturity of female Nile tilapia, Oreochromis niloticus, populations from man-made lakes of cote d'Ivoire. Environ Biol Fish. 1998;52(4):453-65. https://doi.org/10.1023/A: 1007453731509.

Froese R. Cube law, condition factor and weight-length relationships: history, meta-analysis and recommendations. J Appl Ichthyol. 2006;22(4):241-53. https://doi.org/10.1111/j.1439-0426.2006.00805.x.

George FOA, Olaoye OJ, Akande OP, Oghobase RR. Determinants of aquaculture fish seed production and development in Ogun state. Nigeria JSDA. 2010; 12(8):22-34.

Greenwood PH. The fishes of Uganda. 2nd ed. Kampala: The Uganda Society Kampala; 1966.

Gunnarsson A, Hjorleifsson E, Thorarinsson K, Marteinsdottir G. Growth, maturity and fecundity of wolffish Anarhichas lupus L. in Icelandic waters. J Fish Biol. 2006;68(4):1158-76. https://doi.org/10.1111/j.0022-1112.2006.00990.x.

Hossain MY, Rahman MM, Miranda R, Leunda PM, Oscoz J, Jewel MAS, Naif A, Ohtomi J. Size at first sexual maturity, fecundity, length-weight and lengthlength relationships of Puntius sophore (Cyprinidae) in Bangladeshi waters. J Appl Ichthyol. 2012;28:818-22. https://doi.org/10.1111/j.1439-0426.2012.02020. $\mathrm{x}$.

Hunter A, Speirs DC, Heath MR. Fishery-induced changes to age and length dependent maturation schedules of three demersal fish species in the firth of Clyde. Fish Res. 2015;170:14-23. https://doi.org/10.1016/j.fishres.2015.05. 004.

Karachle PK, Stergiou Kl. Morphometrics and allometry in fishes. In: Wahl C, editor. Morphometrics. In Tech; 2012. p. 65-86. Available from: http://www. intechopen.com/articles/show/title/morphometrics-and-allometry-in-fishes.

King AJ, Furtbauer I, Mamuneas D, James C, Manica A. Sex-differences and temporal consistency in stickleback fish boldness. PLoS One. 2013;8(12): e81116.

Lam TJ. Environmental influences on gonadal activity in fish. Fish Physiol. 1983;9: 65-116.

Lambert Y, Yaragina NA, Kraus G, Marteinsdottir G, Wright PJ. Using environmental and biological indices as proxies for egg and larval production of marine fish. J Northwest Atl Fish Sci. 2003;33(115):159.

Law R. Fishing, selection, and phenotypic evolution. ICES J Mar Sci. 2000;57(3): 659-68. https://doi.org/10.1006/jmsc.2000.0731

Lone KP, Hussain A. Seasonal and age related variations in the ovaries of Labeo rohita (Hamilton, 1822): a detailed gross and histological study of gametogenesis, maturation and fecundity. Pak J Zool. 2009;41(3):217-39.

Longalong FM, Eknath $\mathrm{AE}$, Bentsen $\mathrm{HB}$. Response to bi-directional selection for frequency of early maturing females in Nile tilapia (Oreochromis niloticus). Aquaculture. 1999;178(1):13-25. https://doi.org/10.1016/S00448486(99)00132-5

Maack G, Segner H. Morphological development of the gonads in zebrafish. J Fish Biol. 2003;62(4):895-906. https://doi.org/10.1046/j.1095-8649.2003. 00074.x.

Mahmood K, Ayub Z, Siddiqui G. Sex-ratio, maturation and spawning of the Indian ilisha, ilisha melastoma (clupeiformes: pristigasteridae) in coastal waters of Pakistan (northern Arabian Sea). Indian J Mar Sci. 2011:40(4):516.

Mair G. Genes and fish: supply of good quality fish seed for sustainable aquaculture. Aquacult Asia. 2002;7(2):25-7.

Morgan MJ, Colbourne EB. Variation in maturity-at-age and size in three populations of American plaice. ICES J Mar Sci. 1999;56(5):673-88. https://doi. org/10.1006/jmsc.1999.0487.

Muwanika VB, Nakamya MF, Rutaisire J, Sivan B. Masembe C (2012) low genetic differentiation among morphologically distinct Labeobarbus species (Teleostei: Cyprinidae) in the Lake Victoria and Albertine basins, Uganda: insights from mitochondrial DNA. Afr J Aquat Sci. 2012;37(2):143-53. https:// doi.org/10.2989/16085914.2012.668850.

Nickolskii GV. Theory of fish population dynamics: as the biological background for rational exploitation and management of fishery resources. Edinburgh: Oliver and Boyd; 1969. p. 323.
Ondhoro CC, Masembe C, Maes GE, Nkalubo NW, Walakira JK, Naluwairo J, Mwanja MT, Efitre J. Condition factor, length-weight relationship, and the fishery of Barbus altianalis (Boulenger 1900) in lakes upper Victoria and Edward basins of Uganda. Environ Biol Fish. 2016:1-12. https://doi.org/10. 1007/s10641-016-0540-7.

Reichard M, Polacik M, Blazek R, Vrtilek M. Female bias in the adult sex ratio of African annual fishes: interspecific differences, seasonal trends and environmental predictors. Evol Ecol. 2014;28(6):1105-20. https://doi.org/10. 1007/s10682-014-9732-9.

Rutaisire J, Booth AJ. Induced ovulation, spawning, egg incubation, and hatching of the cyprinid fish Labeo victorianus in captivity. J World Aquacult Soc. 2004; 35(3):383-91. https://doi.org/10.1111/j.1749-7345.2004.tb00102.x.

Rutaisire J, Levavi-Sivan B, Aruho C, Ondhoro CC. Gonadal recrudescence and induced spawning in Barbus altianalis. Aquac Res. 2015;46(3):669-78. https:// doi.org/10.1111/are.12213.

Smith BB, Walker KF. Spawning dynamics of common carp in the river Murray, South Australia, shown by macroscopic and histological staging of gonads. J Fish Biol. 2004;64(2):336-54. https://doi.org/10.1111/j.0022-1112.2004.00293.x.

Vandeputte M, Quillet E. Chatain B (2012) are sex ratios in wild European sea bass (Dicentrarchus labrax) populations biased? Aquat Living Resour. 2012; 25(1):77-81.

\section{Ready to submit your research? Choose BMC and benefit from:}

- fast, convenient online submission

- thorough peer review by experienced researchers in your field

- rapid publication on acceptance

- support for research data, including large and complex data types

- gold Open Access which fosters wider collaboration and increased citations

- maximum visibility for your research: over $100 \mathrm{M}$ website views per year

At BMC, research is always in progress.

Learn more biomedcentral.com/submissions 